\title{
Total mercury in the fish Trichiurus lepturus from a tropical estuary in relation to length, weight, and season
}

\author{
Scheyla C. T. Barbosa ${ }^{1}$, Monica F. Costa ${ }^{1}$, Mário Barletta ${ }^{1}$, David Valença Dantas ${ }^{1}$, \\ Helena A. Kehrig² and Olaf Malm²
}

The Goiana River Estuary $\left(7^{\circ} 30^{\prime} \mathrm{S} 34^{\circ} 47^{\prime} \mathrm{W}\right)$ is a typical estuary of the semi-arid tropical regions. This estuary shelters a rich fauna of fish, crustaceans and mollusks which play an important role in the life of traditional populations. It is also the main recipient of the effluents from the sugarcane agro-industry and sewage from settlements and villages. Trichiurus lepturus $(n=104)$, from the Goiana Estuary were examined for total mercury contents during ten months (2005 to 2007) spaning two dry seasons and part of a rainy season. The studied individuals showed weight $(\mathrm{W})(204.1 \pm 97.9 \mathrm{~g})$ and total length (TL) (63.1 10.1 $\mathrm{cm}$, range 29.5-89.0 $\mathrm{cm})$ with a significant $(\mathrm{p}<0.05)$ correlation. Correlation between $\mathrm{TL}$ and $\mathrm{Hg}-\mathrm{T}(\mathrm{r}=0.37286)$ and between $\mathrm{W}$ and $\operatorname{Hg}-\mathrm{T}(\mathrm{r}=0.38212)$ were positive and significant $(\mathrm{p}<0.05)$. Two-way ANOVA $(\mathrm{n}=81)$ showed that $\mathrm{TL}$ and $\mathrm{W}$ had significant difference $(p<0.05)$ among seasons. The Hg-T showed differences in relation to the factor season $(p<0.05)$. The correlation between Hg-T and rainfall showed a negative and significant relation $(r=-0.56 ; p<0.05)$. Rainfall strongly influenced the bioacumulation of mercury in this species. Dryer months showed relatively higher mercury concentrations than the end of the rainy season. Less rainfall, and consequently less particulate matter and less primary production in the estuary, make mercury more bioavailable. Fish from this estuary are fit for human consumption at all times of the year.

O estuário do rio Goiana $\left(7^{\circ} 30^{\prime} \mathrm{S} 34^{\circ} 47^{\prime} \mathrm{W}\right)$ é um típico estuário de região tropical semi-árida. Esse estuário abriga uma fauna rica de peixes, crustáceos e moluscos que tem um importante papel na vida da população tradicional. Ele também é o principal receptor de efluentes da agroindústria da cana-de-açúcar e esgoto das comunidades e vilas. Trichiurus lepturus $(\mathrm{n}=104)$, do estuário do rio Goiana foram examinados para o conteúdo de mercúrio total durante dez meses (2005 a 2007) ao longo de duas estações secas e parte de uma estação chuvosa. Os indivíduos estudados apresentaram peso (P) $(204,1 \pm 97,9$ g) e comprimento total $(\mathrm{CT})(63,1 \pm 10,1 \mathrm{~cm}$, variação $29,5-89,0 \mathrm{~cm})$ com uma correlação significativa $(\mathrm{p}<0,05)$. As correlações entre CT e Hg-T $(r=0,37286)$ e entre $\mathrm{Pe} \mathrm{Hg}-\mathrm{T}(\mathrm{r}=0,38212)$ foram positivas e significativas. AANOVA ( 2 fatores $)(\mathrm{n}=81)$ mostrou que o CT e P apresentaram diferenças significativas $(p<0,05)$ entre as estações. O Hg-T apresentou diferença em relação ao fator estação $(p<0,05)$. A correlação entre $\mathrm{Hg}$ - $\mathrm{T}$ e a chuva apresentou uma relação negativa e significativa $(r=-0,56 ; p<0,05)$. A precipitação pluviométrica influenciou fortemente a bioacumulação de mercúrio nessa espécie. Os meses secos apresentaram relativamente concentrações de mercúrio maiores do que o final da estação chuvosa. Isso sugere que a menor precipitação pluviométrica, e consequentemente a menor quantidade de material particulado e menor produtividade primária no estuário, torna o mercúrio mais biodisponível. Peixes desse estuário podem ser consumidos pela população humana ao longo de todo ano.

Key words: Estuarine fish, Mercury bioavailability, Risk assessment, Seasonal changes, Trichiuridae.

${ }^{1}$ Departamento de Oceanografia, Universidade Federal de Pernambuco. 50740-550 Recife, PE, Brazil. tinocoscheyla@gmail.com (SCTB) ${ }^{2}$ Instituto de Biofísica Carlos Chagas Filho, Universidade Federal do Rio de Janeiro. 21941-900 Rio de Janeiro, RJ, Brazil. 


\section{Introduction}

Due to its high toxicity and association with historic events of contamination in aquatic environments, mercury occupies a place of prominence among heavy metals (Kasper et al., 2007). It is known to be a persistent environmental pollutant (McAloon \& Mason, 2003) and to suffer a number of transformations in the aquatic environment once directly or indirectly introduced. It is an element that has both natural and anthropogenic sources (OSPAR, 2004) to coastal environments, usually gaining access to it through estuaries.

The presence and behaviour of mercury in aquatic systems is then of great interest and importance. Also, it is the only heavy metal which bioaccumulates and biomagnifies through all levels of the aquatic food web (Lindqvist et al., 1991; Kehrig et al., 1998). Mercury levels in marine organisms tend to increase with growth and trophic level (Cronin et al., 1998; Power et al., 2002; Kehrig et al., 2009; Seixas et al., 2009).

Fish are considered good indicators for the evaluation of mercury pollution (Kasper et al., 2007) and, are also an important fisheries resource (Hylander et al., 2000). The presence of mercury in fish allows for the assessment of the metal's bioavailability in aquatic systems. Fish of different species have been frequently used as bioindicators of environmental contamination by mercury in estuaries (Kehrig et al., 2002; Sarger, 2002; Kehrig et al., 2004; Weis \& Ashley, 2007). Top predators can be used as bioindicator of mercury contamination and biomagnification. Fish consumed by human populations, can be used to monitor aspects of mercury contamination of aquatic environments related to human health (Malm et al., 1995; Al-Majed \& Preston, 1999) and resource sustainability. Several species of fish use tropical estuaries as nursery, feeding grounds, and shelter at different stages of their life cycles (Beck et al., 2001; Blaber, 2007).

Variations in the concentrations of mercury in fish may also be linked to the migration of fish to areas where food is more, or less, contaminated, and will also depend on the residence time in each area (Francesconi \& Lenanton, 1992; Al-Majed \& Preston, 1999). Seasonal differences in fish mercury levels (Weis et al., 1986; Kehrig et al., 1998; Weis \& Ashley, 2007) due to different environmental factors were attributed to differences in temperature, dissolved oxygen levels and aquatic primary production (Huchabee et al., 1979).

Trichiurus lepturus Linnaeus, 1758 is a cosmopolitan species that occurs along the whole tropical and sub-tropical latitude belt, including the Western Atlantic and the Brazilian coast (Figueiredo \& Menezes, 2000; Martins \& Haimovici, 2000; Di Beneditto \& Ramos, 2004; Barletta et al., 2005; Martins et al., 2005; Di Beneditto \& Siciliano, 2007; Barletta et al., 2008). Trichiurus lepturus is near the top of the marine food web. It is preyed by many species of cetaceans, seals, sharks, and consumed by human coastal populations (Di Beneditto \& Ramos, 2004; Garcia-Rodriguez \& AuriolesGamboa, 2004; Di Beneditto \& Siciliano, 2007). It is fished using a number of different techniques from shallow estuaries, where it is fished with artisanal tools, to deep waters where it can be accidentally captured in tuna long lines (by catch). This species is a marine straggler (Barletta \& Blaber, 2007; Elliot et al., 2007), switching between estuaries and the adjacent seas as life cycle and food supplies demand.

The present study aimed at determining the concentration of total mercury (Hg-T) in the muscle of Trichiurus lepturus and its relations with biological variables (weight and length), as well as to detect seasonal variations related to the tropical rainfall regime. It was also verified if the level of mercury in fish was within the limit allowed by the World Health Organization (WHO) for safe human consumption. This study was the first in tropical South America to systematically use $T$. lepturus as bioindicator of mercury pollution and, to our knowledge, the first in the world comparing levels of mercury in this species along seasons.

\section{Material and Methods}

\section{Study area}

The Goiana Estuary ( $7^{\circ} 30^{\prime} \mathrm{S} 34^{\circ} 47^{\prime} \mathrm{W}$ ) has $17 \mathrm{~km}$ of main channel from Goiana City to its mouth, and spreads across an area of $\sim 475000 \mathrm{~m}^{2}$, including the floodplain (Fig. 1). The area is encircled by mangrove lined shores and islands. The estuary shelters a rich fauna of fish, crustaceans and mollusks which play an important role in the lives of traditional populations, determining quality and quantity of their subsistence catch and artisanal fisheries activities (Barletta \& Costa, 2009). In this estuary, T. lepturus is frequently consumed and sold by the local population. It is a typical estuary of the semi-arid tropical regions, and the Brazilian East coast has dozens of small estuaries with similar natural and anthropic characteristics. The mangrove forests surrounding the estuary are rapidly losing area to sugarcane plantations and urban areas. This estuary is the main recipient of the effluents from the sugarcane agroindustry and sewage from settlements and villages. However, it is generally considered to be well preserved, due to the remaining extents of mangrove forests.

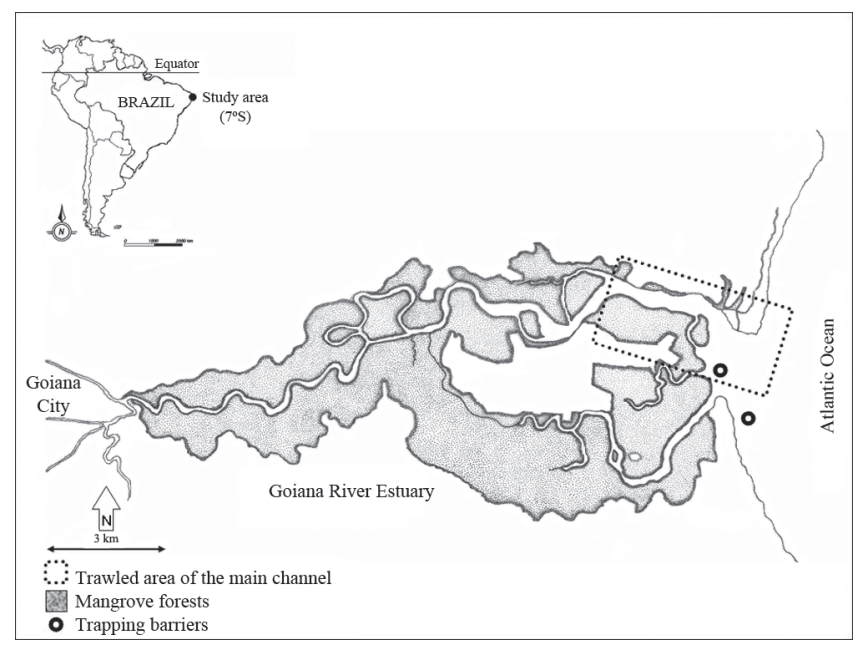

Fig. 1. Location and details of the study area, Goiana Estuary at the Brazilian Northeast. 
It supports traditional communities with fisheries (mollusks, fish and crustacean), wood from mangroves and some small tourist business and its associated services (ferry boat, bars and restaurants).

\section{Fish samples}

Fish samples $(n=104)$ were taken from the low estuary from November 2005 to February 2006 and August 2006 to January 2007, at a trapping barrier (Barletta et al., 1998) used by the traditional community, which works as a fish trap or fish weir. Samples were also taken with an otter trawl net along the main channel of the low estuary (Barletta et al., 2005).

Individuals were measured (total length in $\mathrm{cm}$ ) and weighed $(\mathrm{g})$ immediately after sampling. A sample from the back dorso-lateral muscle was removed from each individual (FAO/SIDA, 1983). Tissue samples were placed in disposable plastic centrifuge tubes, labeled and frozen $\left(-18^{\circ} \mathrm{C}\right)$. All tissues were freeze-dried and lost $75 \%$ water, on average.

\section{Mercury analysis}

A muscle sample of $0.05 \mathrm{~g}$ (dry weight) was acid digested with $3.0 \mathrm{~mL}$ of a $\mathrm{H}_{2} \mathrm{SO}_{4}: \mathrm{HNO}_{3}(1: 1 \mathrm{v} / \mathrm{v})$ mixture and $1.0 \mathrm{~mL}$ of $\mathrm{H}_{2} \mathrm{O}_{2}$ in an open system at $65^{\circ} \mathrm{C}$ for 1 hour, or until a complete digestion. Potassium permanganate $\left(\mathrm{KMnO}_{4}\right)$ was added and after cooling for $24 \mathrm{~h}$, and just before mercury determination, samples were clarified with hydroxylamine, and completed with Milli-Q water. Mercury was determined by cold vapor atomic absorption spectrometry (FIMS - Perkin Elmer AS 90), using sodium borohydride $\left(\mathrm{NaBH}_{4}\right)$ as the reducing agent (Kehrig et al., 2006; Kehrig et al., 2008).

Precision and accuracy of the analytical methods were determined and monitored using certified reference materials obtained from the Intenational Atomic Energy Agency (IAEA 436 - tuna fish muscle). The analytical results showed good precision and accuracy (Table 1).

Except when related to human intake (based on wet weight), all other total mercury concentration results presented here are on a dry weight base.

\section{Statistical analysis}

Statistical analyses were perfomed using STATISTICA ${ }^{\circledR}$ 6.0 for Windows (StatSoft, Inc. 1984-2001, USA). Linear regressions were used to test the existence of relationships between the biological variables (weight and total length), the concentration of total mercury and rainfall. Total mercury concentration and weight data were log-transformed.

Two-way ANOVA was used to test differences in concentration of total mercury among seasons and months (dry season 1: November 2005, December 2005, January 2006; end rainy season: August 2006, September 2006, October 2006; dry season 2: November 2006, December 2006 and January 2007) and total length and weight among seasons and months. The Cochran's test was used to check the homogeneity of variances. Tukey's test ( pos hoc; $\mathrm{p}<0.05$ ) was used whenever significant differences were detected (Quinn and Keough, 2003).
Table 1. Certified reference values and analyzed values for total mercury $\left(\mu \mathrm{gHg} \cdot \mathrm{g}^{-1}\right)$ in certified standard materials TORT-2 (lobster hepatopancreas) and IAEA 436 (tuna fish).

\begin{tabular}{cccc}
\hline & $\begin{array}{c}\text { Certified } \\
\text { Reference } \\
\text { Value }\end{array}$ & $\begin{array}{c}\text { Present study } \\
(\text { April/2007) } \\
(\mathrm{n}=8)\end{array}$ & $\begin{array}{c}(\text { January/2007) } \\
(\mathrm{n}=10)\end{array}$ \\
\hline Mean \pm S.D. & Mean \pm S.D. & \\
\hline $\begin{array}{c}\text { TORT-2 } \\
(\text { NRCC) }\end{array}$ & $0.27 \pm 0.06$ & $0.24 \pm 0.1$ & $0.29 \pm 0.03$ \\
\hline $\begin{array}{c}\text { IAEA 436 } \\
(\text { IAEA) }\end{array}$ & $4.64 \pm 0.26$ & $4.32 \pm 0.56$ & - \\
\hline
\end{tabular}

\section{Results}

\section{Rainfall}

The total monthly precipitation in the area can be divided in four main hydrological seasons (Barletta et al., 2005). The months during the present work spanned across two dry seasons and one rainy season. During D1, dry season 1 (November 2005 to January 2006) mean $( \pm \mathrm{SD})$ rainfall was $12.7 \pm 4.2 \mathrm{~mm}$. During $\mathrm{R}$, the end of the rainy season (August 2006 to October 2006) mean $( \pm \mathrm{SD})$ rainfall was $91.2 \pm 89.2 \mathrm{~mm}$. Finally in D2, dry season 2 (November 2006 to January 2007) mean $( \pm \mathrm{SD})$ rainfall was $91.5 \pm 12.9 \mathrm{~mm}$ (Fig. 2). There was no T. lepturus capture during the early rainy season of 2006.

\section{Biological variables and Total mercury concentration in Trichiurus lepturus - Seasonal variations.}

Mean $( \pm$ SD $)$ weight $(204.1 \pm 97.9 \mathrm{~g}$; total biomass $=222.7 \mathrm{~g})$ and total length $(63.1 \pm 10.1 \mathrm{~cm}$; range $29.5-89.0 \mathrm{~cm})$ showed that the studied group $(\mathrm{n}=104)$ was composed of sub-adult $(30-70 \mathrm{~cm} ; \mathrm{n}=71)$ and adult fish $(>70 \mathrm{~cm} ; \mathrm{n}=33)$ according to the size intervals for the Western Atlantic (Martins \& Haimovici, 1997). The analysis of all samples $(n=104)$ of Trichiurus lepturus presented a positive and significant $(p<0.05)$ correlation between weight and total length $(r=0.8273)$ (Fig. 3a). The correlation between total length and log total mercury concentrations $(\mathrm{r}=0.37286)$ was also positive and significant $(\mathrm{p}<0.05)$ (Fig. 3b). The correlation $(\mathrm{r}=0.38212)$ between weight and log total mercury was similarly positive and significant $(\mathrm{p}<0.05)$ (Fig. 3c).

ANOVA $(n=81)$ showed that total length had a significant difference $(\mathrm{p}<0.05)$ among seasons. Total length in D1 was greater than in D2 and R, respectively (Fig. 4a). There was a significant interaction between factors season and month. Weight showed a significant difference $(\mathrm{p}<0.05)$ for the factors season and month. In D1 weight was greater than in D2 and R respectively (Fig. 4b). Also, a significant interaction between the factors season and month was found. Log total mercury concentrations in T. lepturus differed significantly among seasons $(\mathrm{p}<0.05)$. Total mercury concentrations in D1 were greater than in D2 and R respectively (Fig. 4c). Significant differences among the months comprising each season were not detected for $\log$ total mercury concentrations. Significant interactions between the factors season and month were not observed in relation to log total mercury concentrations. 
Table 2. Biological parameters and respective mean total mercury concentrations ( $\mu \mathrm{gHgT.} \mathrm{kg}^{-1}$ in the muscle) of Trichiurus lepturus from Goiana Estuary in the study period.

\begin{tabular}{|c|c|c|c|c|c|}
\hline Seasons & Year & $\mathrm{N}$ & $\begin{array}{l}\text { Lenght }(\mathrm{cm}) \\
\text { Mean } \pm \text { SD } \\
\text { (Range) }\end{array}$ & $\begin{array}{c}\text { W eight }(\mathrm{g}) \\
\text { M ean } \pm \text { SD } \\
\text { (Range) }\end{array}$ & $\begin{array}{c}\mu \mathrm{gHg}-\mathrm{T} \cdot \mathrm{kg}^{-1} \\
\text { Mean } \pm \mathrm{SD} \\
(\text { Range) } \\
\end{array}$ \\
\hline D1 & $2005 / 2006$ & 27 & $\begin{array}{c}67.0 \pm 6.8 \\
(56.0-79.6)\end{array}$ & $\begin{array}{c}256.0 \pm 73.7 \\
(107.5-387.0)\end{array}$ & $\begin{array}{c}773.4 \pm 207.5 \\
(408.7-1283.4)\end{array}$ \\
\hline $\mathrm{R}$ & 2006 & 27 & $\begin{array}{c}54.2 \pm 9.8 \\
(26.0-69.0)\end{array}$ & $\begin{array}{c}104.6 \pm 55.9 \\
(18.6-252.0)\end{array}$ & $\begin{array}{c}331.2 \pm 138.5 \\
(154.3-654.1)\end{array}$ \\
\hline D2 & $2006 / 2007$ & 27 & $\begin{array}{c}66.8 \pm 7.4 \\
(53.0-78.0) \\
\end{array}$ & $\begin{array}{c}220.9 \pm 73.0 \\
(113.0-354.1)\end{array}$ & $\begin{array}{c}370.1 \pm 78.8 \\
(241.5-551.6) \\
\end{array}$ \\
\hline
\end{tabular}

When comparing D1, R and D2, it was observed that in D1, individuals showed a slightly larger length, more weight and higher concentrations of mercury (Table 2). The correlation $(\mathrm{r}=-0.56)$ between rainfall and log total mercury was negative and significant $(\mathrm{p}<0.05)$ (Fig. 5).

\section{Mercury concentration in Trichiurus lepturus: is Human consumption possible?}

Average total mercury in fish muscle during the present work was $501.0 \pm 247.5 \mu \mathrm{gHg}-\mathrm{T} . \mathrm{kg}^{-1}$ dry wt., corresponding to 125.3 $\pm 61.9 \mu \mathrm{gHg}-\mathrm{T} . \mathrm{kg}^{-1}$ wet wt. (Table 3). It follows that D1 had an average total mercury content of $193.4 \pm 51.9 \mu \mathrm{g} . \mathrm{kg}^{-1}$ wet wt.; R $82.8 \pm 34.6 \mu \mathrm{g} . \mathrm{kg}^{-1}$ wet wt. and; D2 showed a mean mercury concentration of $92.5 \pm 19.7 \mu \mathrm{g} . \mathrm{kg}^{-1}$ wet wt (Table 2). The World Health Organization Provisional Tolerable Weekly Intake (PTWI) allows the ingestion of $3.3 \mu \mathrm{gHg}-\mathrm{T} . \mathrm{kg}^{-1}$ per week (wet wt.) for the general population. A $70 \mathrm{~kg}$ person, eating $100 \mathrm{~g}$ of T. lepturus from the Goiana Estuary daily, would ingested, on average, $1.26 \mu \mathrm{g}$ of total mercury per week. In D1 this intake would be of $1.96 \mu \mathrm{g}$ per week; R $0.84 \mu \mathrm{g}$ per week and, D2 $0.91 \mu \mathrm{g}$ per week (Table 2).

\section{Discussion}

Trichiurus lepturus was not captured during the early and high rainy seasons at the Goiana Estuary using the available techniques. Probably during this time it seldom penetrates the estuary since shoals of its main prey (sardines and anchovies) are not present either (Bittar et al., 2008). Both, pray and predator, probably remain along the coast where salinity is more stable at this time of the year (Barletta et al., 2005), which confirms its status as a marine straggler reported in the literature (Barletta \& Blaber, 2007; Elliot et al., 2007).

Correlations between size and concentration of total mercury and weight and concentration of total mercury confirm that this metal is undergoing bioaccumulation in piscivorous fish of this species at the Goiana Estuary. The correlation between mercury concentration and biological parameters in fish can be influenced by age/growth rate, season and food availability (quantity and quality) (Huchabee et al., 1979; Kehrig et al., 1998). The present results suggest a process of bioaccumulation of mercury at the Goiana Estuary, which may be noted by the increase in the concentration of total mercury in fish with the increase of size and weight. This same correlation of increased concentration

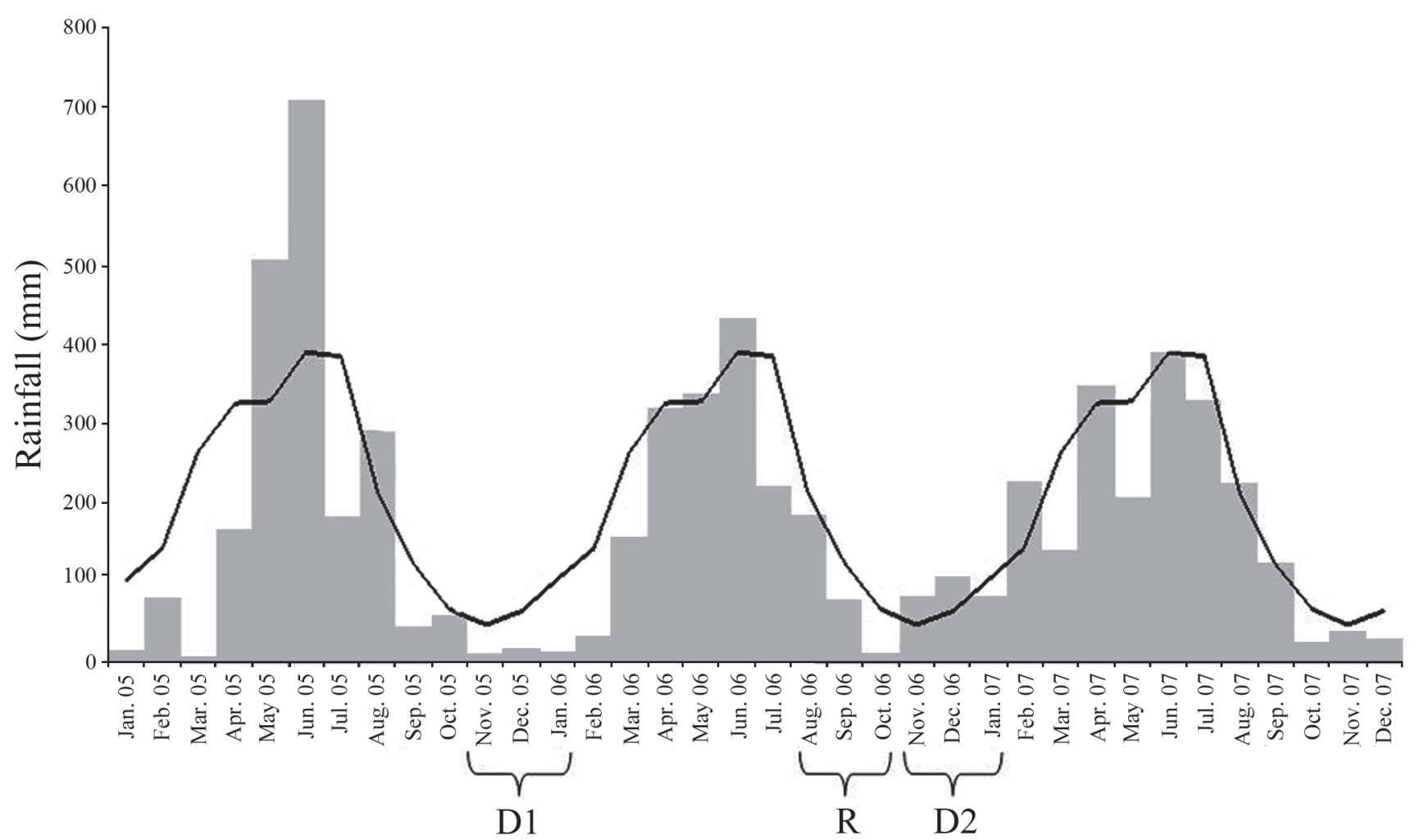

Fig. 2. Rainfall in the study area from a historic (1961 to 1990) data set (solid line) and from 2005-2007 (bars). Source: http:// www.inmet.gov.br - meteorological station Recife-82.898). 

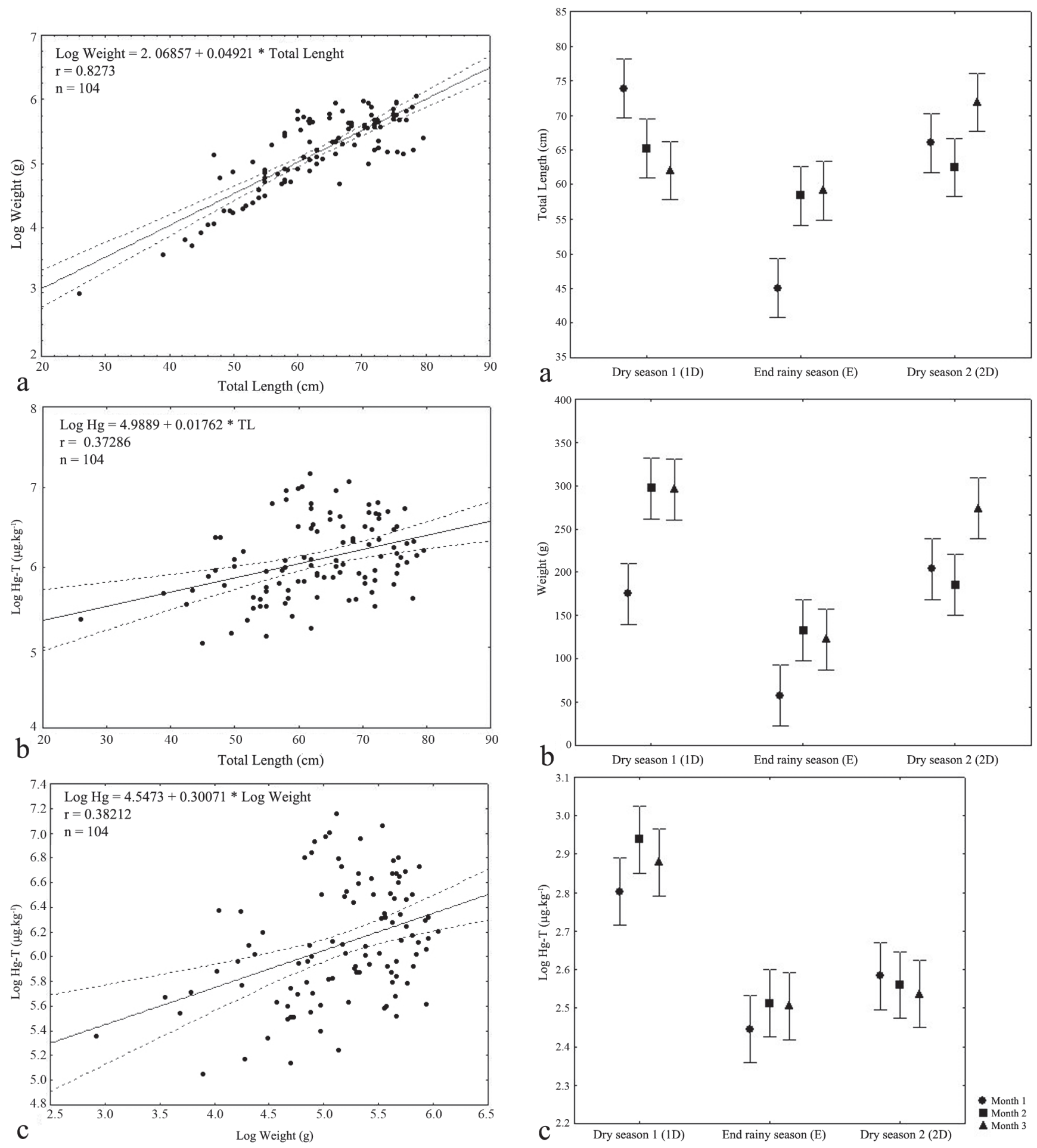

Fig. 3. Correlations $(\mathrm{n}=104)$. a. $\log$ weight $(\mathrm{g})$ in respect to total length $(\mathrm{cm}) ; \mathbf{b} . \mathrm{Log}\left(\mathrm{mgHg}-\mathrm{T} . \mathrm{kg}^{-1}\right.$ in the muscle) in relation to total length $(\mathrm{cm}) ; \mathbf{c}$. $\log (\mathrm{mgHg}-\mathrm{T} . \mathrm{kg}-1)$ in relation to $\log$ weight ( $\mathrm{g}$ ) of Trichiurus lepturus from the Goiana Estuary from November 2005 to January 2007. All plots show a 95\% confidence interval.

Fig. 4. Two-way ANOVA. a. Total length (cm); b. Weight (g); c. $\log \left(\mathrm{mgHg}-\mathrm{T} . \mathrm{kg}^{-1}\right.$ in the muscle) considering seasons and months $(1=$ dry season 1 - November and December 2005, January 2006; 2 = end of the rainy season - August to October 2006; 3 = dry season 2 - November and December 2006, January 2007). 
Table 3. Comparisons of (Mean \pm S.D.) lenght $(\mathrm{cm})$, weight $(\mathrm{g})$, total mercury concentration in the muscle $\left(\mathrm{mgHg}-\mathrm{T} . \mathrm{kg}^{-1}\right)$ and mean estimates of weekly intake (assuming a regular consumption of $100 \mathrm{~g}$ fish.day ${ }^{-1}$ wet wt.) for Trichiurus lepturus from four different countries/regions based on WHO (1976, 1989). a. Present study; b. Prudente et al., 1997; c. Mol et al., 2000; d. Kehrig et al., 2004; e. Kehrig et al., 2009.

\begin{tabular}{|c|c|c|c|c|c|c|}
\hline Country & $\mathrm{N}$ & $\begin{array}{l}\text { Length }(\mathrm{cm}) \\
\text { (Range) }\end{array}$ & $\begin{array}{l}\text { Weight }(\mathrm{g}) \\
\text { (Range) }\end{array}$ & $\begin{array}{c}\mu \mathrm{gHg}-\mathrm{T} . \mathrm{kg}^{-1} \text { (dry wt.) } \\
\text { (Range) }\end{array}$ & $\mu \mathrm{gHg}-\mathrm{T} \cdot \mathrm{kg}^{-1}$ (wet wt.) & $\begin{array}{c}\mu \mathrm{gHg}-\mathrm{T}_{\mathrm{kg}}{ }^{-1} \text { (wet wt.) } \\
\text { per week }\end{array}$ \\
\hline Brazil $^{\text {a }}$ & 104 & $\begin{array}{c}63.1 \pm 10.1 \\
(26.0-79.6)\end{array}$ & $\begin{array}{c}204.1 \pm 97.9 \\
(18.6-424.0)\end{array}$ & $\begin{array}{c}501.0 \pm 247.5 \\
(154.3-1283.4)\end{array}$ & 125.3 & 1.26 \\
\hline Philippines ${ }^{\text {b }}$ & 1 & 51.0 & & 123.0 & 30.8 & 0.31 \\
\hline Suriname $^{c}$ & 2 & $\begin{array}{c}114.8 \pm 5.9 \\
(110.6-119.0)\end{array}$ & $\begin{array}{c}1190.0 \pm 490.0 \\
(843.0-1536.0)\end{array}$ & $\begin{array}{c}620.0 \pm 28.3 \\
(600.0-640.0)\end{array}$ & 155.0 & 1.55 \\
\hline Brazil $^{\mathrm{d}}$ & 28 & $\begin{array}{c}87.5 \pm 19.3 \\
(62.0-138.0)\end{array}$ & $\begin{array}{c}515.2 \pm 350.7 \\
(180.0-1360.0)\end{array}$ & $\begin{array}{c}312.6 \pm 156.8 \\
(152.0-840.0)\end{array}$ & 78.2 & 0.78 \\
\hline $\mathrm{Brazil}^{\mathrm{e}}$ & 17 & & & $1070 \pm 1060$ & 267.5 & 2.68 \\
\hline
\end{tabular}

of total mercury with length and weight of fishes, was also observed for other species in other situations (Kehrig et al., 1998; Pinho et al., 2002; Kehrig et al., 2004; Adams \& Onorato, 2005; Weis \& Ashley, 2007).

A lower concentration of mercury in fish will be expected with higher precipitation. This can be explained by the dilution of mercury in the larger volumes of water and adsorption onto particulate matter that will be directly exported to the sea without a long residence time within the estuary. With more rainfall in dry season 2 , the estuary presented a predominantly eutrophic condition with a lot of suspended matter entering the system. Both these factors dilute mercury inputs, with a consequent decrease of its bioavailability (Kehrig et al., 1998; Kehrig et al., 2001), resulting in lower mercury concentrations in fish.

The main likely source of mercury to this estuary is diffuse land runoff. The lower basin of the Goiana River is almost totally taken by sugarcane plantations and urban areas,

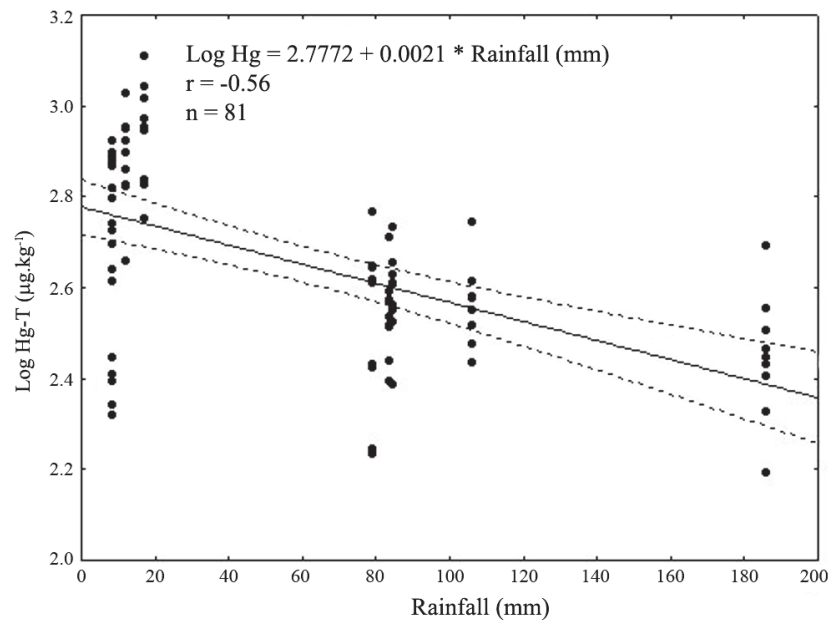

Fig. 5. Correlation $(\mathrm{n}=81)$ between rainfall $(\mathrm{mm})$ and $\log$ ( $\mu \mathrm{gHg}-\mathrm{T} . \mathrm{kg}^{-1}$ in the muscle) of Trichiurus lepturus from the Goiana Estuary $(1=$ dry season 1 - November and December 2005, January 2006; 2 = end of the rainy season - August to October 2006; 3 = dry season 2 - November and December 2006, January 2007). leaving only a very narrow mangrove fringe around the estuary. Urban effluents contribution is another probable source, since the area has no sewage treatment systems.

When Trichiurus lepturus preys inside estuaries, probably it is contaminated with mercury due to the trophic transfer of this element along the food web, which has been acknowledged as an important process influencing bioaccumulation (Fisher \& Reinfelder, 1995). When leaves to coastal waters $T$. lepturus acts as a transporting agent of mercury from the estuary to the sea. When consumed by its own predators such as Sotalia guianensis (Cetacea: Delphinidae) (Di Beneditto \& Ramos, 2004; Di Beneditto \& Siciliano, 2007), T. lepturus will transfer its mercury burden to other levels of the marine trophic web.

There are only few studies considering mercury contamination of this socially and economically important species at estuarine and coastal regions around the world. Most of them have limited number of individuals and time span. Comparing total mercury (wet wt.) in Trichiurus lepturus from the Goiana Estuary - Brazilian Northeast: $125.3 \mu \mathrm{gHg}$ T. $\mathrm{kg}^{-1}$ wet wt., with results from Guanabara Bay - Brazilian Southeast: $78.2 \mu \mathrm{gHg}-\mathrm{T} . \mathrm{kg}^{-1}$ wet wt. (Kehrig et al., 2004), Suriname: $155.0 \mu \mathrm{gHg}-\mathrm{T} . \mathrm{kg}^{-1}$ wet wt. (Mol et al., 2000), Philippines: $30.8 \mu \mathrm{gHg}-\mathrm{T} . \mathrm{kg}^{-1}$ wet wt. (Prudente et al., 1997), and the Northern Coast of Rio de Janeiro - Brazilian Southeast: $267.5 \mu \mathrm{gHg}$-T. $\mathrm{kg}^{-1}$ wet wt. (Kehrig et al., 2009), it is seen that at all sites fish are below the limit suggested by the WHO (500 $\mu \mathrm{gHg}-\mathrm{T} . \mathrm{kg}^{-1}$ wet wt.), above which regular human consumption should be controlled.

When present in shallow coastal and estuarine waters $T$. lepturus is frequently captured and consumed by traditional populations as those living around the Goiana Estuary. In the present results indicate that $T$. lepturus did not exceed the WHO-PTWI of maximum $3.3 \mu \mathrm{gHg}-\mathrm{T} . \mathrm{kg}^{-1}$ per week, and can continue to be part of the daily diet of the local population. However, pregnant women and small children should avoid frequent consumption of this species since, for these groups, T. lepturus in this estuary are near the tolerable limit for safe regular ingestion, in this cases, a maximum of $1.6 \mu \mathrm{gHg}-\mathrm{T} . \mathrm{kg}^{-1}$ per week. 


\section{Conclusions}

The total mercury concentration in T. lepturus at Goiana Estuary suggested bioaccumulation, because the increasing concentration of total mercury presented direct relation to length and weight of individuals observed.

Mercury concentrations were inversely correlated to rainfall. Differences in mercury concentrations were also detected for the two subsequent dry seasons.

Fish from the Goiana Estuary can still be safely consumed by the local population. The proposed heavy dependency of total mercury levels in fish from water quality indicates that land use practices must be closely watched in order to guarantee the best possible options are put in place to prevent water contamination and food web bioaccumulation and biomagnification.

Trichiurus lepturus is largely consumed by coastal populations of tropical and sub-tropical countries all over the world. It is also consumed by a number of marine mammals over which there is a strong conservation interest. Therefore knowledge of its degree of contamination might contribute to public health issues as well as marine conservation actions. Studies on mercury and other contaminants including this species as bioindicator could help elucidate mechanisms through which pollutants are being transferred not only through the food web, but also from estuarine to coastal and finally to open waters, since this species is a marine straggler and promotes a link among different ecosystems along this ecocline. In addition, using the same species in marine pollution studies, especially if part of a mosaic of species, allows for wide range comparisons of marine food web contamination.

\section{Acknowledgements}

The authors would like to thank the Conselho Nacional de Desenvolvimento Científico e Tecnológico - CNPq (grant \# 474736/2004-0) for the financial support of this project, research scholarships of Scheyla Barbosa, David Dantas, as well as research grants for Mário Barletta, Helena Kehrig, and Olaf Malm.

\section{Literature Cited}

Adams, D. H. \& G. V. Onorato. 2005. Mercury concentrations in red drum, Sciaenops ocellatus, from estuarine and offshore waters of Florida. Marine Pollution Bulletin, 50: 291-300.

Al-Majed, N. B. \& M. Preston. 1999. An assessment of the total and methylmercury content of zooplankton and fish tissue collected from Kuwait territorial waters. Marine Pollution Bulletin, 40: 298-307.

Barletta, M., C. S. Amaral, M. F. M. Corrêa, F. Guebert, D. V. Dantas, L. Lorenzi \& U. Saint-Paul. 2008. Factors affecting seasonal variations in demersal fish assemblages at an ecocline in a tropical-subtropical estuary. Journal of Fish Biology, 73: $1-23$.
Barletta, M., A. Barletta-Bergan \& U. Saint-Paul. 1998. Description of the fisheries structure in the mangrove-dominated region of Bragança (State of Para, North Brazil). Ecotropica, 4: 41-53.

Barletta, M., A. Barletta-Bergan, U. Saint-Paul \& G. Hubold. 2005. The role of salinity in structuring the fishing assemblages in a tropical estuary (Caeté River - East Amazon - Brazil). Journal of Fish Biology, 66: 45-72.

Barletta, M. \& S. J. M. Blaber. 2007. Comparison of fish assemblages and guilds in tropical habitats of the Embley (Indo-West Pacific) and Caeté (Western Atlantic) estuaries. Bulletin of Marine Science, 80: 647-680.

Barletta, M. \& M. F. Costa. 2009. Living and non-living resources exploitation in a tropical semi-arid estuary. Journal of Coastal Research, 56: 371-375.

Beck, M. W., K. L. Heck, K. W. Able, D. L. Childers, D. B. Eggleston, B. M. Gillanders, B. Halpern, C. G. Hays, K. Hoshino, T. J. Minello, R. J. Orth, P. F. Sheridan \& M. P. Weinstein. 2001. The identification, conservation, and management of estuarine and marine nurseries for fish and invertebrates. Bioscience Journal, 51: 633-639.

Bittar, V. T., B. F. L. Castello \& A. P. M. Di Beneditto. 2008. Hábito alimentar do peixe-espada adulto, Trichiurus lepturus, na costa norte do Rio de Janeiro, sudeste do Brasil. Biotemas, 21: 83-90.

Blaber, S. J. M. 2007. Mangroves and fishes: issue of diversity, dependence, and dogma. Bulletin of Marine Science, 80: 457472.

Cronin, M., I. M. Davies, A. Newton, J. M. Pirie, G. Topping \& S. Swan. 1998. Trace metal concentrations in deep-sea fish from the North Atlantic. Marine Environmental Research, 45: 225238.

Di Beneditto, A. P. M. \& R. M. A. Ramos. 2004. Biology of the marine tucuxi dolphin (Sotalia fluviatilis) in south-eastern Brazil. Journal of the Marine Biological Association of the United Kingdom, 84: 1245-1250.

Di Beneditto, A. P. M. \& S. Siciliano. 2007. Stomach contents of the marine tucuxi dolphin (Sotalia guianensis) from Rio de Janeiro, south-eastern Brazil. Journal of the Marine Biological Association of the United Kingdom, 87: 253-254.

Elliot, M., A. K. Whitfield, I. C. Potter, S. J. M. Blaber, D. P. Cyrus, F. G. Nordlie \& T. D. Harrison. 2007. The guild approach to categorizing estuarine fish assemblages: a global review. Fish and Fisheries, 8: 241-268.

FAO/SIDA, 1983. Manual de Métodos de Investigación del Medio Ambiente Acuático. Parte 9. Análisis de Presencia de Metales y Organoclorados en los Peces. FAO, Doc. Téc. Pesca, 212: 135.

Figueiredo, J. L. \& N. A. Menezes. 2000. Manual de peixes marinhos do sudeste do Brasil. VI. Teleostei (5). Museu de Zoologia, São Paulo, USP, 116p.

Fisher, N. S. \& J. R. Reinfelder. 1995. The trophic transfer of metals in marine system. Pp. 363-406. In: Tessier, A. \& D. R. Turner (Eds.). Metal Speciation and Bioavailability in Aquatic Systems. New York, John Wiley \& Sons, 661p.

Francesconi, K. \& R. C. J. Lenanton. 1992. Mercury contamination in a semi-enclosed marine embayment: organic and inorganic mercury content of biota, and factors influencing mercury levels in fish. Marine Environmental Research, 33: 189-212.

Garcia-Rodriguez, F. J. \& D. Aurioles-Gamboa. 2004. Spatial and temporal variation in the diet of the California sea lion (Zalophus californianus) in the Gulf of California, México. Fishery Bulletin, 102(1-4): 47-67. 
Huchabee, J. W., J. W. Elwood \& S. C. Hildebrand. 1979. Accumulation of mercury in freshwater biota. Pp. 277-302. In: Nriagu, J.O.(Ed.). The biogeochemistry of mercury in the environment. Amsterdam, Elsevier, 696p.

Hylander, L. D., F. N. Pinto, J. R. D. Guimarães, M. Meili, L. J. Oliveira \& E. C. Silva. 2000. Fish mercury concentration in the Alto Pantanal, Brazil: influence of season and water parameters. Science of the Total Environment, 261: 9-20.

Kasper, D., D. Botaro, E. F. A. Palermo, O. Malm. 2007. Mercúrio em peixes - fontes e contaminação. Oecologia Brasiliensis, 11: 228-239.

Kehrig, H. A., J. L. Brito Jr., O. Malm \& I. Moreira. 2004. Methyl and total mercury in the food chain of a tropical estuary-Brazil. RMZ-Materials and Geoenvironment 51: 1099-1102.

Kehrig, H. A., M. Costa, O. Malm \& I. Moreira. 2002. Total and methylmercury in a Brazilian estuary, Rio de Janeiro. Marine Pollution Bulletin, 44: 1018-1023.

Kehrig, H. A., M. Costa, I. Moreira \& O. Malm. 2001. Methylmercury and total mercury in estuarine organisms from Rio de Janeiro, Brazil. Environmental Science \& Pollution Research, 8: 275-279.

Kehrig, H. A., M. Costa, I. Moreira \& O. Malm. 2006. Total and methyl mercury in different species of mollusks from two estuaries in Rio de Janeiro State. Journal of Brazilian Chemical Society, 17: 1409-1418.

Kehrig, H. A., K. W. G. Fernandes, O. Malm, T. G. Seixas, A. P. M. Di Beneditto \& C. M. M. Souza. 2009. Tranferência trófica de mercúrio e selênio na costa norte do Rio de Janeiro. Química Nova, 32: 1822-1828.

Kehrig, H. A., O. Malm \& I. Moreira. 1998. Mercury in a widely consumed fish Micropogonias furnieri (Demarest, 1823) from four main Brazilian estuaries. Science of the Total Environment, 213: 263-271.

Kehrig, H. A., T. G. Seixas, E. A. Palermo, A. P. M. Di Beneditto, C. M. M. Souza \& O. Malm. 2008. Different species of mercury in the livers of tropical dolphins. Analytical Letters, 41: 1691-1699.

Lindqvist, O., K. Johnasson, M. Aastrup, A. Andersson \& L. Bringmark. 1991. Mercury in the Swedish environment recent research on causes, consequences and corrective methods. Water, Air and Soil Pollution, 55: 1-251.

Malm, O., F. J. P. Branches, H. Akagi, M. B. Castro, W. C. Pfeiffer, M. Harada, W. R. Bastos \& H. Kato. 1995. Mercury and methylmercury in fish and human hair from the Tapajós river basin, Brasil. Science of the total Environment, 175: 141-150.

Martins, A. S. \& M. Haimovici. 1997. Distribution, abundance and biological interactions of the cutlassfish Trichiurus lepturus in the southern Brazil subtropical convergence ecosystem. Fisheries Research, 30: 217-227.

Martins A. S. \& M. Haimovici. 2000. Reprodution of the cutlassfish Trichiurus lepturus in the southern Brazilian subtropical convergence ecosystem. Scientia Marina, 64: 97-105.
Martins, A. S., M. Haimovici \& R. Palacios. 2005. Diet and feeding of the cutlassfish Trichiurus lepturus in the subtropical convergence ecosystem of southern Brazil. Journal of the Marine Biological Association of the United Kingdom, 85: 217-227.

McAloon, K. M. \& R. P. Mason. 2003. Investigations into the bioavailability and bioaccumulation of mercury and other trace metals to the sea cucumber, Sclerodactyla briareus, using in vitro solubilization. Marine Pollution Bulletin, 46: 1600-1608.

Mol, J. H., J. S. Ramlal, C. Lietar \& M. Verloo. 2000. Mercury contamination in freshwater, estuarine and marine fishes in relation to small-scale gold mining in Suriname, South America. Environmental Research, 86: 183-187.

OSPAR Commission, 2004. Mercury losses from the Chlor - Alkali Industry (1982-2002).

Pinho, A. P., J. R. D. Guimarães, A. S. Martins, P. A. S. Costa, G. Olavo \& J. Valentin. 2002. Total mercury in muscle tissue of five shark species: effects of feeding habits, sex, and length. Environmental Research, 89: 250-258.

Power, M., G. M. Klein, K. R. R. A. Guiguer \& M. K. H. Kwan. 2002. Mercury accumulation in the fish community of a subArtic lake in relation to trophic position and carbon sources. Journal of Applied Ecology, 39: 819-830.

Prudente, M., E. Y. Kim, S. Tanabe \& R. Tatsukawa. 1997. Metal levels in some commercial fish species from Manila Bay, the Philippines. Marine Pollution Bulletin, 34: 671-674.

Sarger, D. R. 2002. Long-term variation in mercury concentrations in estuarine organisms with changes in releases into Lavaca Bay, Texas. Marine Pollution Bulletin, 44: 807-815.

Seixas, T. G., H. A. Kehrig, A. P. M. Di Beneditto, C. M. M. Souza, O. Malm \& I. Moreira. 2009. Trace element in different species of cetacean from Rio de Janeiro. Journal of Brazilian Chemical Society, 20: 243-251.

Weis, P., J. S. Weis \& J. D. Bogden. 1986. Effects of environmental factors on release of mercury from Berry's Creek (New Jersey) sediments and its uptake by killifish Fundulus heteroclitus. Environmental Pollution 40: 303-315.

Weis, P. \& J. T. F. Ashley. 2007. Contaminants in fish of the hackensack meadowlands, New Jersey: size, sex, and seasonal relationships as related to health risks. Archives of Environmental Contamination and Toxicology, 52: 80-89.

World Health Organization. 1976. Environmental Health Criteria 1: Mercury. Geneva, WHO.

World Health Organization. 1989. Toxicological evaluation of certain food additives and contaminants in WHO Food Additives Series. Cambridge Univ. Press, Cambridge, 295-328p.

Accepted November 24, 2010 Published March 31, 2011 